The Geneva Papers on Risk and Insurance, 22 (No. 82, January 1997) 86-106

\title{
A Consideration of Pension Credit and Termination Insurance in the UK
}

\author{
by Steven Haberman*
}

\begin{abstract}
Summary
Recent events in the UK, and in particular the scandal associated with the business affairs of the late $\mathrm{R}$ Maxwell, have led to a thorough public scrutiny of the laws and regulation of occupational pension schemes. The Pension Law Review Committee has considered and reported on inter alia, the establishment of a "pension compensation fund". The purpose of this paper is to abstract from some of the current details of the debate in the UK and to consider the issues associated with pension credit and termination insurance as alternative means of operating and financing a pension compensation fund, to cover the contingency of underfunding in the event of the insolvency of the sponsoring employer.
\end{abstract}

\section{Introduction}

The House of Commons Social Committee's inquiry into the operation of pension funds in the UK was announced in July 1991. It was widely believed at that time that the Committee's principal concern was the operation of personal pension funds (rather than occupational pension schemes). However, the pension scandal centred on the affairs of the late $R$ Maxwell became public in early December 1991 and the Committee's attention was duly refocused. The Committee reported in public on this part of their inquiry in March 1992. The report was wide-ranging and critical of the then current organisation and practices of occupational pension schemes. One of the Committee's recommendations was that the "inquiry we have advocated should urgently consider whether to establish a pension compensation fund...".

Subsequently, the law and regulation of occupational pension schemes was considered by the Pension Law Review Committee, set up under the Chairmanship of Professor Roy Goode in June 1992. The Review Committee published an extensive consultation document which ended with a set of questions ( 81 in number) on which the Committee wished to receive comments. A number of these questions addressed the issues of a compensation scheme and minimum funding.

* Department of Actuarial Science and Statistics, City University, London. The author would like to acknowledge the helpful comments made by his collaegue, Zaki Khorasanee, and by the referees on an earlier draft. 
The two main questions associated with a "pension compensation fund" were

(a) What contingencies (i.e. events and losses) should be covered?

(b) How should the compensation fund be financed?

The contingencies that might be covered include: fraud, maladministration, theft, underfunding in the event of voluntary termination of the scheme.

The Review Committee published its report on 30 September 1993. It recommended the establishment of a non-retrospective compensation scheme, with compensation limited to loss resulting from fraud, theft or other "dishonest misappropriation" of pension scheme assets. Some further details are provided in the next paragraphs.

In this context, dishonest misappropriation would include employees' contributions being dishonestly applied by the employer for some purpose of his own. The compensation scheme would cover all funded occupational pension schemes, including insured schemes. An independent pensions compensation board would be established to run the compensation scheme and would have the sole right to decide whether a claim should be paid in any particular case. Any compensation payment would take the form of a lump sum and would be a loan which is repayable only from any recoveries.

Compensation would only be payable after default by the company on the debt due to the pension scheme if a deficiency had been created. The compensation to be paid would be the lower of $90 \%$ of the value of the misappropriated assets and $90 \%$ of the amount of any scheme deficit (based on the minimum solvency standard basis). The pensions compensation board would have the power to determine how the payment to the scheme should be used, and could disregard the scheme's priority rules.

The cost of the compensation scheme would be met by an ex-post levy on all occupational schemes, based on the size of the scheme's minimum solvency liabilities. The pension compensation board would have borrowing powers to cover any payments made in advance of any levy. In defined contribution schemes, the employer would be required to pay an additional contribution equal to any payment from the pension scheme to the compensation scheme.

If we now turn to the list of contingencies that might be covered by a pension compensation scheme, there are methodological difficulties associated with modelling the contingencies of fraud, maladministration and theft. Hence, in this paper we do not consider these contingencies.

Like the Pension Law Review Committee, we recognise the significant risk related to the shortfall in assets for a defined benefit scheme arising from a fall in the market value of the investments. But the Committee's recommendation for a supervised minimum solvency margin (now referred to as a minimum funding requirement in subsequent legislation), coupled with prudent investment diversification, would imply that only a severe and widespread fall in investment values would be liable to give rise to problems. It is doubtful whether in such circumstances any compensation scheme would be easily able to manage the heavy losses to which it would be exposed. Further, it would be necessary to recognise the inequity of seeking to protect defined benefit pension scheme members from investment risks while defined contribution pension scheme members receive no such protection.

For these reasons in this paper, we move away from the above particular proposals and instead concentrate on the contingency of "underfunding in the event of employer insolvency", and we consider only the case of defined benefit schemes (typically providing 
benefits related to final salary). We shall consider the interesting problem of how pension credit insurance and pension termination insurance might be used as a means of meeting this contingency, and hence as a possible means of operating and financing a "pension compensation fund". It is hoped that this discussion might have relevance both to the UK and to other countries with significant defined benefit occupational pension provision.

\section{Current protection in UK in event of employer's insolvency}

In the UK, the employer's insolvency remains a source of insecurity for scheme members' pension rights, despite the extensive use in the UK of external funding.

Some statutory provisions have been introduced in recent years to mitigate partially the possible losses.

\subsection{Priority claims on employer}

Pension schemes have certain priorities over other creditors in the event of the employer's bankruptcy (under Social Security Pensions Act 1975). All schemes have priority regarding members' contributions deducted from pay in the last 4 months but not handed over to the scheme. Contracted-out schemes have a priority in respect of employer's unpaid contributions over the last 12 months, up to the amount needed to secure pensions in payment and accrued Guaranteed Minimum Pensions (GMPs).

If the employer has few assets, these priorities are worthless.

\subsection{Debt on employer regulations}

If a scheme is wound up and there are insufficient assets in the fund to secure the promised wind-up benefits, then the shortfall is now to be a debt on the employer's assets. Provision was made for this in the Social Security Act 1990 but it came into force on 1 July 1992 with the making of the Occupational Pension Schemes (Deficiency on Winding Up) Regulations 1992. The details of these regulations remain to be clarified - for example, there appears to be no reference to the actual cost of securing the promised wind-up benefits, for example by the payment of premiums to an insurance company or to the National Insurance Fund (McLeish and Stewart, 1992). For an ongoing company with a scheme which has insufficient assets to cover its discontinuance liabilities, it is also not clear how, if at all, an auditor will reflect this potential liability in the company's accounts (Marshall and Reeve, 1993).

\subsection{Employment Protection Acts 1975,1978}

Under these Acts, where an employer has insufficient assets to meet the claims of his pension scheme, the scheme may receive some limited help from the Redundancy Fund. The Fund does not have any commitment to render solvent a scheme put in difficulties by an insolvent employer. The Fund pays any members' contributions deducted from pay by the employer but not paid over to the scheme in the last 12 months prior to the insolvency. The Fund also pays the minimum of

(a) the amount needed to meet the scheme's liabilities;

(b) the employer's contributions due but unpaid over the last 12 months;

(c) $10 \%$ of the earnings of the scheme members over the last 12 months. 
The Fund is financed by a levy on employers, related to payroll. It thus provides a small-scale form of credit insurance, which is subject to arbitrary limits and leaves room for possible loss of sizeable pension rights.

The Department of Social Security (DSS) have accepted a recommendation of the Occupational Pensions Board (OPB) that in the event of the insolvency of employer or of an insurance company, these arrangements would be extended to pay any premiums necessary to buy the members of a contracted-out occupational pension scheme back into the State earning-related pension scheme (SERPS).

\section{Pension credit insurance or pension termination insurance}

In Appendix I, we review the pension credit insurance and pension termination insurance systems in operation in other countries. In countries like Sweden, Finland and Germany, where internal or book reserve funding is the normal financing system for occupational pensions, pension credit insurance has been developed to provide protection against the employer becoming insolvent. In contrast, the US, which has funded occupational pension schemes like the UK, has operated a system of pension termination insurance, insuring the scheme rather than the employer. Thus, two separate methods of providing coverage in the event of the employer becoming insolvent, have been developed.

Pension credit insurance is a system under which employers pay premiums to an insurance organisation which guarantees that, if the employer becomes bankrupt, contractual pension obligations to the scheme members (and pensioners) will be met, to the extent that they are not already covered through insurance policies or segregated pension fund assets.

Systems of this type have existed in Finland, Sweden and Germany. It has been common practice in Sweden and Germany for pension obligations to be financed by reserves in the employer's accounts (so-called "book reserves") rather than by insured schemes or segregated funds, and there is a legal obligation for those book reserves to be covered by credit insurance. In Finland, credit insurance has been used to insure the liabilities of pension funds as a guarantee for the assets and to insure unfunded liabilities. Also, the scheme assets may be lent back to the employer and, in this situation, credit insurance must be effected.

Termination insurance is a different system which has been adopted in the USA. Under this system, an employer who operates a pension plan that is qualified for tax purposes must fund it to certain minimum standards. Termination insurance must be effected to cover the risk that, on termination of the plan, vested pension rights may not be fully covered by the plan assets. There is a first charge on the employer of $30 \%$ of his net worth, and the insurance takes effect only if this charge on the employer's assets (the Employers' Contingent Liability - ECL) is insufficient. The insurance cover is provided by the Pension Benefit Guarantee Corporation (PBGC).

There is an inherent problem of potential abuse (moral hazard) in any form of insurance where the insurable event (here, the winding-up of a pension scheme) is under the control of the insured (here, the sponsoring employer). The first charge on the employer's assets is designed to limit this problem.

Also, termination insurance would require the imposition of minimum funding levels, with consequent restrictions on the flexibility of funding methods and actuarial assump- 
tions, and the supervision of these funding levels. Some employers may regard these factors in a negative light, although scheme members and beneficiaries may regard them as advantageous.

There are similarities between this system of pension termination insurance and the US system for publicly insuring the deposits of commercial banks (as provided through the Federal Deposit Insurance Corporation (FDIC)) and the failed system for insuring savings and loans associations (through the Federal Savings and Loans Insurance Corporation).

As a general point, we note the comment made by Bride and Lomax (1994) that whenever there are asymmetric claims on an asset, altering the variability of these claims or of the underlying asset will result in transfers of wealth between different claimants. Any form of guarantee results in such an asymmetry and leads to the potential for wealth transfers and cross subsidies. The guarantees implied by a credit or termination scheme would lead to such asymmetries and so careful consideration needs to be given to the potential for, and management of, moral hazard and cross subsidies. These points are addressed in the next section.

\section{Possible system of pension credit insurance}

The practicalities of setting up a system of pension credit insurance in the UK are discussed in this section. Some important issues of theoretical nature are also considered. We extend a number of the suggestions put forward in Appendix 3 of the report of the OPB (1982).

\subsection{Coverage}

It is proposed that the system should, in principle, be compulsory for all employers with contractual obligations, through a defined benefit occupational pension scheme, to pay retirement benefits to their employees. This compulsory feature would be desirable for reasons of equity and spreading the risk and would help to maintain the stability of the premiums charged and the overall financial strength of the insuring body. It would also avoid the possibility of employers remaining out of the scheme and then opting into the scheme when they had perceived that the risk of bankruptcy had increased.

We would need to consider whether both self-administered and insured pension schemes should be included. Since beneficiaries of UK insured schemes are substantially covered by the provisions of the Policyholders Protection Act 1975 against possible asset deficiencies, it is suggested that the system need only cover self-administered pension schemes.

There are some multi-employer schemes in existence and their inclusion would require special arrangements for allocating the premiums fairly between the participating employers.

Small schemes could be included even though the associated administrative work may be demanding, because it is among smaller employers that the risk of insolvency and inadequately funded pensions is likely to be significant. However, in the UK, there are likely to be difficulties with including the Small Self-Administered Schemes (SSAS), which have a special status with the Inland Revenue (Kipling, 1984). An important feature of these schemes is that a high degree of self investment is permitted (up to $50 \%$ of the market value of the assets for a scheme which has been in operation for 2 years). In order to make maximum utilisation of the available tax reliefs, many such schemes are strongly funded. But the introduction of a pension credit insurance scheme which covered SSAS's would lead to a significant moral hazard (arising, inter alia, from this high degree of self investment allowed) for a sponsoring employer facing ruin. 
Also, there are a large number of Executive Pension Schemes in existence. These are insurance contracts classified as one-person occupational pension schemes, designed for company directors, and should be excluded from coverage, for the same reason as insured schemes (see above).

It would be administratively convenient if the proposed credit insurance scheme were effected by the employer with the premiums payable by the employer (as discussed in section 3 , rather than any part being paid by the members of the pension scheme).

\subsection{Contingencies on which claims would be paid}

Under the proposed system a claim would arise if the employer became insolvent and, on winding-up the pension scheme (or schemes), if the scheme assets (and any charge on the employer's assets) were insufficient to enable the trustees to secure the promised windup benefits, (by purchasing insurance premiums and, where appropriate, paying State scheme premiums to the UK National Insurance Fund).

Since 1 July 1992, there has been legislation in place (under Social Security Act 1990) requiring any such shortfall to be charged first to the employer's assets. It is, therefore, proposed that, only if that charge could not be met in full, would there be a call on the credit insurance policy. This requirement would lead to fairness in treatment for the employees between the case of a solvent employer winding up a scheme and an employer becoming insolvent.

A question arises as to whether it would be necessary to wait for the employer's bankruptcy before the credit insurance provider is involved. Should the contingencies covered extend beyond employer insolvency? For example, in Sweden, the insurer steps in and makes payments when the employer fails to make clearly defined benefit payments. In the USA, the primary purpose of the termination insurance plan is to provide protection to the scheme participants and their beneficiaries against the financial consequences of a scheme termination. The phrase "scheme termination" is not defined by ERISA and it has been necessary for the PBGC to develop its own working definition. The PBGC may institute proceedings to terminate a scheme if

(i) it finds that the scheme breaks the minimum funding standards; or

(ii) the scheme is unable to pay benefits when due; or

(iii) the eventual loss to the PBGC may reasonably be expected to increase dramatically if the scheme were not immediately wound up.

(We note that voluntary termination by the employer was permitted until recent reforms within the PBGC's termination insurance scheme).

For our purposes, we shall concentrate on the more tightly worded definition given above, i.e. dependent on employer insolvency.

\subsection{Benefits}

A difficult question is the extent to which pension scheme beneficiaries should be entitled to non-contractual benefits on the winding up of a scheme. This is important because post retirement discretionary pensions increases are a common feature of provision in the UK. Thus, according to the 1987 Survey of occupational pension schemes, carried out by the Government Actuary (1991), 84\% of private sector pensioners were in schemes which had granted at least one increase in their pensions in payment during 1984-86, with a very high 
proportion receiving annual increases. On average the increases, where granted, have been broadly in line with inflation over this period, but there have been wide variations between schemes. In the public sector, increases have followed closely the movements in the Retail Prices Index (for statutory reasons).

If there were no entitlement to such discretionary increases, there would be inequity between these recently retired and those more elderly pensioners (who could face the loss of a sizeable portion of their pension income).

It is therefore proposed that the benefits to be guaranteed for employees in service under this credit insurance scheme would be the minimum wind-up benefits, according to the legislation (or the scheme rules if they permit higher benefits) in force at the termination date, with an allowance for discretionary pension increases at a rate representative of the recent practice of the pension scheme. Similarly, for pensioners and deferred pensioners, the benefits would be those to which they had a contractual entitlement, together with an allowance for discretionary pension increases.

The cost of these benefits would be assessed by reference to the prevailing premium rates in the insurance market. So the credit insurance sum insured would be the difference between the "market" value of the winding up benefits and the market value of the assets available to cover these liabilities, assessed at an annual valuation date. There may be difficulties in assessing the market values of property and non-quoted securities - these problems exist for normal valuations and are not insuperable.

The scheme assets available to count against the value of the accrued liabilities should, in principle, exclude self-investment in the shares of the employer. The credit insurance system would need to include rules regarding self-investment and, if necessary, an over concentration of investments and would need to exclude certain categories of assets from consideration. This will place an upper bound on the riskiness of the assets being deemed to serve as backing for the liabilities.

To prevent possible abuse, it might be desirable to give the supervisory body the power to exclude from coverage any benefits of an exceptional nature granted by the employer within the past three years, say.

A modification might also be necessary to ensure that active members should not be turned into deferred pensioners or early retirement pensioners just prior to the insolvency date with the intention that they would thereby join the highest priority class. Further, it should be noted that, under current UK legislation, active members have the right to become deferred pensioners at any time by opting out of their occupational pension scheme (without necessarily leaving the sponsoring employer). It would thus be necessary to impose a qualifying period so that deferred and early retirement pensioners would be given equal priority with the active members, unless they had completed the qualifying period.

This system would be an alternative to:

(a) one where all schemes were obliged to operate at least to meet a specified minimum funding standard; or

(b) one where the actuary to the scheme was free to recommend a basis for determining the value of the liabilities for the purposes of the credit insurance system.

Under (a), it would be likely that a minimum funding standard would become the norm, which would have the consequence of reducing the security of pension scheme members' rights. If the standard were set too low, then premiums to the credit insurance system 
would need to be high to pay the benefit obligations, and there would likely be criticisms of the degree of subsidy being imposed on well funded schemes. If the standard were set too high, then sponsoring employers would be dissatisfied with a situation where large margins were being held in the form of assets which might belong to the scheme members and would not be recoverable by the employer.

Under (b), the actuary to the scheme would accept the responsibility for determining the sum insured under the system. On grounds of equity between schemes and avoiding undue pressure being placed on the actuary by an unscrupulous employer, it would seem reasonable to avoid such a system and opt instead for a system where the sum insured is fixed in relation to legislative requirements and the scheme rules relating to winding-up.

\subsection{Monitoring}

As Bodie and Merton (1992) note, monitoring is a widely used mechanism for managing explicit and implicit guarantees within financial systems. In this case, the supervision body would need to monitor the market value of the pension scheme assets in relation to the value of the liabilities, to ensure that these assets were sufficient to enable the trustees to meet the cost of the wind-up benefits in the event of the sponsoring employer becoming insolvent. This monitoring could be implemented through the submission of a valuation report from the pension scheme actuary, on an annual basis. As in other circumstances, it would then be necessary for the actuarial profession to devise acceptable rules and methods for the performance of this valuation, without being too prescriptive (or constraining professional judgement).

\subsection{Premium assessment per scheme}

There would appear to be two different conceptual approaches to the calculation of the premium for the proposed credit insurance scheme:

(a) a conventional risk premium approach

(b) an option pricing approach.

Both are discussed in the following paragraphs (and Appendix II).

\subsubsection{Risk premium approach}

Under a risk premium approach, the premium is assessed on an annual basis as the product of a premium rate and the relevant sum insured (in the same way as a private insurer would set a premium rate). The premium is thus proportional to the sum insured, setting aside the question of expense loadings.

It is proposed that the annual premium (for the proposed credit insurance scheme) in respect of each employer would be a percentage of the sum insured, defined as the difference between the present value of the wind-up benefits and the value of the assets available to cover those liabilities. Practically, the sum insured would have to be calculated at the start of each insurance year and would be assumed to remain constant over the year. Given the delays in carrying out the necessary calculations, the premium payable in advance for any year would probably need to be based on the sum insured one year previously (or, alternatively there could be an adjustment premium paid at the year end). The valuation of wind-up benefits and relevant assets would be carried out on consistent bases and methods fixed by 
statute, using, for example, a discounted cash flow or notional fund approach to the valuation of the assets. This would ensure that the premiums charged from year to year would not fluctuate too greatly for any scheme.

The UK Pension Scheme Surpluses (Valuation) Regulations 1987 require the valuation of assets and liabilities on consistent bases, with assets being valued using a discounted cash flow approach. But the actuarial liability is based on accrued benefits (in the event of retirement, withdrawal or death) rather than accrued wind-up benefits and the prescribed assumptions are fairly conservative. However, these Regulations may provide a starting point, with some amendments, for our purposes.

It is proposed that, in the event of an employer becoming insolvent, the benefits payable under the proposed system are fixed in relation to the market value of the wind-up benefits, (allowing for discretionary benefits, as discussed at the start of section 4.3) to be determined by the cost of the appropriate insurance company premiums (for immediate and deferred annuities), and the market value of the associated assets. In making this proposal, it is recognised that there are potential practical problems arising from the use of "buy out" annuity premiums. Firstly, there is the question of the capacity of the market: a concern of the Pension Law Review Committee. Secondly, there is the pricing methodology used by insurance companies: it would be normal to include margins for expenses, solvency, mortality improvement, indexation in line with inflation. The combined effect of these factors would be to increase the premium rates. It would be noted that large schemes may be in a position to negotiate the "buy-out" terms. The significance of these points would be greater in the context of measuring the solvency of all pension schemes or in the context of assessing risk premia for credit insurance for all schemes in relation to the much smaller number of schemes that would be actually winding up from time to time. A third difficulty would be the need, in some cases, to purchase annuities that incorporate a fixed rate of escalation of benefits (as discussed at the start of section 4.3).

Premiums relating to the size of insured benefit (as proposed) rather than a per capita assessment (as for the PBGC in the USA) would seem more equitable, given the nature of the insurance scheme.

An important consideration is whether the premiums should be related to a measure of risk (e.g. credit worthiness or the excess of the employer's assets over liabilities) or should be on a flat-rated basis.

Risk-adjusted premiums would reflect the probability of the employer's insolvency and would possibly be based on the employer's financial standing, measured for example by the ratio of the employer's assets to liabilities (which might be difficult to assess, although this has been implemented practically in Finland).

The alternative would be for the premiums to be a flat percentage of the sum insured, with the percentage being the same for all employers, assuming that the membership and benefit coverage are known in advance.

A system with premiums related to credit worthiness would lead logically to an employer becoming uninsurable or becoming unable to pay the high premiums at the time when the protection was most needed. The financially strong employers could avoid paying premiums by funding to a level such that the value of the winding up benefits was fully covered by the segregated assets. It could then be argued that, from the viewpoint of the scheme members, it is a matter of good or bad luck whether their employer is in a strong or weak 
financial position. The fundamental purpose of the credit insurance is to provide all scheme members with the same, high standard of pension security - this argument leads to the suggestion that the burden of eliminating insecurity should be borne equally by all.

If it were felt that the level of cross-subsidies and the moral hazard and adverse selection problems inherent in such a flat premium rated scheme were too high, then it would be appropriate to relate the premium in some way to the employer's financial strength. As Moeller (1992) and Bodie and Merton (1992) have pointed out, there is a strongly held view that the PBGC termination insurance scheme in the USA is helping to subsidise failing industries: the ability to gain assistance from the PBGC indirectly through plan termination may be burdening the financially viable companies and offering the weaker enterprises an incentive to underfund their pension obligations. This is an issue with important political and social ramifications.

On balance, it is felt that the balance of the argument favours the risk-adjusted premium approach.

The mathematical details of the premium formula are presented in Appendix II.

As proposed by Urrutia (1990) in a different context, it would be possible to adapt this system of full insurance also to include coinsurance, a deductible and both a deductible and coinsurance as different means of lowering the premium to be charged and sharing the risk between the insurance provider and the sponsoring employer.

The primary source of finance for the body operating the credit insurance would be premium income. Secondary sources would include the recoveries from the available assets of employers for whom the insurer has had to act and investment earnings on funds built up by the insurer from earlier income. Subsidies or loans from Government authorities may also be possible.

\subsubsection{Comments on other countries}

The risk premium approach is effectively used in Sweden, Finland and the USA for premium assessment.

In Sweden, credit insurance cover can be refused or withdrawn (in which case the employer must secure the benefits directly with an insurance company and not use book reserves). The same flat rate percentage premium rate is used for all employers. The calculation is further greatly simplified by "standardised" benefits, a standard actuarial basis and the central registration of benefits.

By contrast, in Finland, cover cannot be declined. The premium rate is risk-related and the measure used for assessing a company's financial standing is the ratio of the company's assets to its liabilities.

In the USA, the termination insurance run by the PBGC has premiums of a flat amount per member, although there is a legislative provision for premiums to be related to the unfunded pension liability and the total pension liability. Recent reforms have meant that risk-related premiums (a per capita premium related to the degree of underfunding) have been introduced. In a similar vein, Urrutia (1990) has advocated a risk-adjusted insurance premium to be charged by the FDIC and proposes a model for determining such premia. He argues strongly that the use of a flat premium rate reduces market discipline and encourages insured banks to increase their exposure to risk (by reducing their assets: deposit ratio or by undertaking riskier loans). 
The Swedish system of excluding the weaker employers appears to work because there is the practical alternative of requiring that the excluded employers secure the occupational pensions by direct purchase from an insurance company. If such a system were applied in the UK, the scale of such purchases could be significant in view of the larger magnitude of occupational pension provision. There appears room for doubt whether such a system could be routinely applied in the case, for example, of a major UK pension fund, if the position were reached where the employer were no longer acceptable for credit insurance. The transfer of liabilities from the pension fund to a life insurer inight be enormous. Presumably, the life insurer would have to be asked to accept the assets of the fund in lieu of more conventional methods of paying premiums; otherwise, there would have to be a liquidation procedure. If several large funds were so involved at any one time, there could be significant effects on investment markets with possibly even a wider detrimental effect on the economy.

So, it does not appear realistic to deny credit insurance cover to the weaker employers and require them to make provision for pensions through a life insurance contract.

In both Sweden and Finland, the premium rate is applied to the actuarial liabilities of the pension scheme measured in some way, using the risk premium methodology.

Under the German system, the total premium income each year is related to the number of actual bankruptcies and a percentage premium rate is set so as to provide the required monies. The premium is thus effectively a levy. A financing system based on levies (designed to meet costs after the event) has been proposed by Lewin (1992). We believe, however, that a premium based system would be more equitable in principle and less indiscriminate than a levy based system.

\subsubsection{Option pricing approach}

An alternative method for determining quantitatively the value of the premium rate and the liabilities under a credit insurance scheme, such as that proposed, is to use the methodology of option pricing and to recognise explicitly the nature of this insurance as a put option. This will lead to risk-based premiums which, for example, would increase with the variability of the underlying pension scheme assets.

Appendix II provides a discussion of this approach.

The discussion of Appendix II suggests that an option pricing methodology may be useful both for the estimation of the contingent liabilities and of the annual premiums for a credit insurance system such as that being proposed here.

\subsection{Insurance provider}

A further major area to be considered is the nature of the insurance provider. Broadly, there are three possible types of constitution:

(i) a private insurance fund (or funds) run on strictly commercial principles; or

(ii) a mutual insurance fund; or

(iii) an official fund managed by Government.

Worldwide, there are examples of a mutual arrangement organised by the employers in Sweden, an arrangement managed by Government in the USA, an insurance arrangement closely supervised by Government in Finland and in Germany, an association founded by employers, industry and life assurance companies, but with statutory backing. 
These cases should not be classified too strictly. They all, however, involve close Government interest but all are required to be self-financing, having no subsidy or financial guarantee from Government. Comparisons with other countries, however, are of limited value, given that the benefits provided by occupational pension arrangements in the UK are typically of a greater scale than those in Sweden, Finland or Germany, and are more diverse in nature.

An argument in favour of a mutual insurance fund organised by the employers (as in Sweden), rather than coverage being provided by commercially run insurance companies, is that the latter would naturally seek to make a profit out of the policies provided.

The degree of uncertainty in such a credit insurance arrangement, and the potential scale of claims in a catastrophe situation, are such that private insurers might be reluctant to undertake the business. One possibility might, however, be to operate on a private sector consortium basis as in Germany. Under any such system, it would appear necessary that premiums should be assessed on a cost plus expenses and profit margin basis, with provision for a surcharge on employers if current premiums, plus any contingency reserves, proved inadequate.

The alternative of insuring liabilities through a State run organisation, with the State underwriting any catastrophe losses, might be regarded as unsatisfactory in that some part of those losses would have to be met by taxpayers, many of whom would not be involved in any way with occupational pension schemes.

\subsection{Premium income and insurance funds}

We come now to the question of what principles are to be applied in assessing the quantum of monies required to be raised each year (or period) from the premium income and how the permanent funds of the insurance provider are to be held.

Again, we shall firstly consider the principles adopted in various countries.

In the United States, as we have seen, the PBGC has adopted the principle that all premium rates must be sufficient to provide annual revenue which taken together with investment income and employers' contingent liability contributions is sufficient to meet all unfunded actuarial liabilities associated with funds terminating during the year, i.e. not just sufficient to pay the benefits becoming due that year from terminating plans. This principle has been adopted in an attempt to spread the costs fairly over successive generations of plan sponsors. The PBGC has taken the position that the full cost of each year's plan terminations should be borne by the plans subject to the risk of termination during the year, rather than being spread over the priod of the future lifetimes of the participants and beneficiaries whose benefits were insured under the terminated plans. Implementation of this principle means that PBGC must collect premiums each year equal to the actuarial present value of all the benefit payments that it will make in future years in respect of the plans that terminate in that year. This inevitably leads to a substantial accumulation of assets in the termination insurance funds.

In Finland and Sweden, a similar method is used, with all uncovered actuarial liabilities arising in a year being met by the credit insurance system, but with these liabilities being immediately secured by the purchase of pension insurance with a life insurance company. So, a large solvency insurance fund does not build up (representing the liabilities in respect of rescued benefits) as is the case in the United States. However, to the extent that 
premium rates are held constant over successive years to maintain stability, there may be a build up of funds representing a carry-forward of surplus premiums not needed to cover claims in earlier years.

Since the proposed system uses a sum insured in the event of employer insolvency which is sufficient to purchase the wind-up benefits in the prevailing insurance market, it would be consistent for the liabilities assumed by the credit insurer to be transferred to insurance companies by the direct purchase of appropriate contracts. In situations where this is not practicable (e.g. a major pension scheme), the credit insurer would have to take over the responsibility for the actuarial liabilities and the available assets (perhaps in the short term only).

Assuming that the actual claim rates were modest and we were using the risk premium approach (of Section 4.5.1), it would appear simplest and most satisfactory to cover any unfunded liabilities in the funds of insolvent employers completely by premiums raised in the year of insolvency. Then, the liabilities can be protected immediately by purchase with a life insurer (or by placing the necessary assets in the credit insurance fund). However, if it were desirable to slow the pace of funding of the uncovered benefits (for example, in order to reduce the initial cost of the new credit insurance programme), this could be arranged by deferring the purchase of insurance contracts with life insurers or by carrying an unfunded liability in the credit insurance fund.

Regardless of which premium assessment method we would use, the premiums initially could only be assessed roughly. Premiums could be subject to a degree of fluctuation as business conditions changed unless, for example, the amortization approach mentioned in Appendix II were utilised. As surpluses or deficiencies emerge in the insurance fund, future premiums could be adjusted, with suitable provision being made for the build up of some contingency reserves (as appears to be the case in Finland and Sweden).

A debate currently being conducted in the USA concerning the PBGC is how to measure its financial condition and assess its solvency (Moeller 1992). The opposing views are between those who consider the PBGC to be

(a) a social insurance programme, financed on a pay-as-you-go basis, for which cash flow and current funded position would be important,

and those who consider it to be

(b) a private insurance programme for which present values of future liabilities would be important.

This may hint at potential problems if any proposed credit insurance scheme accumulates large potential deficits (as is the current US position for the PBGC).

\subsection{Disclosure}

Disclosure requirements were introduced in the UK in the Social Security Act 1985 and have been subsequently amended, the most recent being the Occupational and Personal Pension Schemes (Miscellaneous) Regulations 1992. It would be important for the level of credit insurance premium each year to be disclosed (and the underlying assessment method), together with the benefits being provided under the credit insurance scheme, as part of the increasing move of employers to communicate more effectively with scheme members regarding the status of the scheme. 


\section{Compulsory credit insurance: advantages and disadvantages}

A system such as the above would provide greater protection for accrued pension entitlements in the UK as defined by the preservation legislation and scheme rules. The employees of an insolvent employer would thus have an improved level of protection. However, it should be noted that, since the credit insurance would come into operation in an individual case once the employing company had been wound up, delays could occur between the date of insolvency and the completion of the winding-up procedure so that the protection provided may not be immediate.

The arrangements would, however, introduce a considerable extra degree of complexity and there would be additional costs in administering the system.

The arrangements would improve the security of employees' accrued benefits (together with the "Debt on the Employer Regulations" operating from 1 July 1992).

The increase in costs may persuade some employers to lower their funding targets and to fund on the basis of the winding-up liabilities in an effort to reduce costs in the short term. Of course, as some commentators have recently pointed out, it is possible for funding on the basis of winding-up liabilities to be more stringent than funding on an ongoing basis (Collins 1992, McLeish and Stewart 1993). Also, it could be argued that employers should increase funding targets so that the probability of a deficiency in accrued benefits would be small and so that much reduced premiums to the credit insurance scheme would be payable (assuming the risk premium basis of section 4.5 .1 were adopted). However, employers might then be less willing to use surpluses to fund improvements in benefits.

The need to pay a premium if assets do not cover winding up liabilities might inhibit employers from introducing improvements in benefits, the initial liability for which they would wish to meet over a period of years. (This might take the form of reduced improvements and/or delayed improvements). However, it can be argued that such improvements ought not to be made unless the employer is able to fund them fairly quickly, and that the need to pay insurance premiums (if the employer cannot do so) may put a desirable degree of restraint on rash promises.

An alternative possible consequence of the introduction of a compulsory credit insurance scheme is that the need to pay a credit insurance premium might lead employers to reduce the rate of future pay increases for all employers, which would indirectly lower the rate of buildup of pension liabilities. Current pension scheme members might prefer such a solution as the most appropriate way of financing the cost of greater future security for their pension benefits. However, this response by employers would involve some inequity since not all employees would necessarily be pension scheme members.

\section{APPENDIX I \\ Review of pension credit and termination insurance systems in operation in other countries}

Internal or book reserve funding is the usual financing system for occupational pensions in a number of countries viz Sweden, Finland, Germany, Austria (Abramson and Carne, 1981). A book-keeping debt is accumulated to which interest is credited and which is backed by the employer's assets. These book-keeping allocations attract tax relief as if they had been payments to an external, segregated fund. 
This system is clearly vulnerable to the bankruptcy of the individual employer. So, a system of credit insurance has been developed in most of the countries where book-reserve funding is the usual practice (excluding Austria).

In Sweden and Germany, the state pension schemes provide relatively high earningsrelated pensions without arrangements for contracting-out by private schemes. The financial problems of operating a credit insurance system are, therefore, correspondingly less severe than they would be in the UK. However, the USA, which has a relatively low level of state scheme provision and has funded occupational pension schemes similar to the UK, has operated a system of termination insurance, insuring the scheme rather than the employer, since 1974 . We shall pay particular attention to the US experience.

We shall consider the practices and experiences of these countries in the following paragraphs. A full review of the systems in a number of countries is provided by Puzey (1979) and OPB (1982).

\section{A.1 Sweden}

In Sweden, social insurance provides a relatively high level of benefit and the private provision of occupational pension benefits is dominated by two nationwide contracts which provide a relatively modest level of benefit, viz the ITP plan for government and salaried employees and the STP plan for wage earners.

Pensions secured by the ITP plan must be either secured with one mutual insurance company or covered by book reserves in the balance sheet of the employer. In this latter case, the employer must belong to a credit insurance system, run by a mutual insurance company, the FPG, set up by the employers. The FPG will only provide credit insurance for employers which it considers are credit worthy. Credit insurance is granted usually for a period of 5 years and the arrangement can be terminated at the end of the period by either the company or the FPG. The FPG can also terminate the insurance earlier if the company looks unable to meet its obligations! The premium for the credit insurance has been set as a percentage of the pension "debt" at the end of the preceding year. The premium is not allowed to vary either by industry or occupation of the employer or according to his financial standing. (However, companies considered weak are required to provide some kind of security to the FPG for their liabilities.)

Under the STP Plan, for all employees who reach retirement age in a calendar year, the capital value of their pensions is calculated. The necessary cost is then levied on all the employers in the STP sector (even those who do not have any STP pensioners). Pension contributions are calculated as a fixed percentage of wages, which is the same for all companies. The pensions are insured with a company (AMF Pension Insurance). Employers can obtain a loan against their pension contributions, provided that credit insurance has been granted (by AMF Credit Insurance).

AMF Credit Insurance only grants cover for companies that it considers are financially sound. If its assets are not sufficient to cover the costs of claims, it has the right to levy a charge (as a non-recurring measure).

\section{A.2 Finland}

In Finland, there is an obligation on employers to provide occupational pensions of a minimum level. Employers provide occupational pension either through insurance, or through a multi-employer pension fund or through a single employer pension fund. 
All pension institutions (funds, foundations or pension insurance companies) are supervised and co-ordinated by the Central Pension Security Institution (CPSI). Employers may borrow back a proportion of the contributions paid (and the remaining funds can be lent to other companies, inter alia).

Credit insurance is provided by the CPSI and is essentially an insurance against the employer's insolvency. There is no Government financial backing or guarantee for the CPSI's insurance arrangements, which must rely solely on premium income, as well as recoveries of assets from insolvent companies. Credit insurance is required for the total minimum pension liabilities of pension funds as a guarantee for the fund's investments, any unfunded minimum liabilities or registered additional voluntary benefits and any permitted loans from pension funds. Unlike the case in Sweden, the CPSI cannot refuse cover but the premium rate may be assessed according to the risk of the employer's insolvency. The company's financial standing is measured by the ratio of assets to liabilities and premium rates are reassessed annually against this ratio.

\section{A.3 Germany}

In Germany, the most widely used method of providing for future pensions is by the establishment of book reserves in the employer's balance sheet.

Book reserves must be protected by insolvency or credit insurance, provided by the PSV, an association set up by the employers and life insurance companies. When an employer becomes insolvent, the PSV takes over the liabilities arising from the book reserves and, when a pension benefit becomes payable, the PSV purchases an annuity directly from an insurer. It appears that premiums are fixed on a basis between the extremes of providing the full actuarial liability in respect of all uncovered benefits arising each year and providing sufficient funds only to meet the benefits payable in that year.

\section{A.4 United States}

In the United States, the Employee Retirement Income Security Act 1974 (ERISA) required that pension plans obtain termination insurance which will insure participants and their beneficiaries against loss of benefits arising from a complete or partial termination of the plan. The Pensions Benefit Guarantee Corporation (PBGC) was established to provide this insurance cover.

If the PBGC were to incur any loss in meeting the benefit obligations of a terminated pension plan, the employer or employers who sponsored the plan must reimburse the Corporation for its loss up to a maximum of $30 \%$ of his net worth (unless the loss is due to the insolvency of an insurance carrier). This liability of the employer is referred to as the "Employers' Contingent Liability" (ECL). The purpose of the ECL is to limit the moral hazard problem as well as to foster a sense of discipline on the employer in setting benefit levels and meeting the accruing costs and to provide a source of financial stability to the PBGC.

Under ERISA, on failure to meet a claim from the PBGC in respect of the Employers' Contingent Liability, the PBGC acquires a lien upon all the property and all the property rights of the employer. This is in fact a very high level of priority of claim exceeded only by secured creditors (and a few other categories). 
The PBGC is required to be self-financing and has no Government guarantee. It derives its sources of funds from four main sources: premium income, investment income, ECL's and monies borrowed from the US Treasury.

The PBGC has adopted the principle that all premium rates must be sufficient to provide annual revenue which taken together with investment income and employers' contingent liability contributions is sufficient to meet unfunded actuarial liabilities associated with pension funds terminating during the year (i.e, not just sufficient to pay the benefits becoming due in the year on terminated plans). This is regarded as a fundamental issue concerning the distribution of the social costs over successive generations of plan sponsors and will lead to substantial accumulations of assets in the guaranty funds.

Premium rates have been set as a levy per member, rather than on the basis of unfunded liability or total liability. The responsibility of paying premiums rests with the scheme administrator and the premiums are paid out of scheme assets. A late payment charge and an interest charge are imposed if the premium is not paid within 60 days of the due date.

There have been some problems with the financing and operation of the US compensation system, leading to a situation where, although annual income is sufficient to meet annual expenditure on benefits and expenses, assets are insufficient to meet current obligations and the resulting gap continues to grow. This has been reviewed fully by McGill and Grubbs (1989 - Chapter 24), Moeller (1992) and Bodie and Merton (1992). Since the PBGC was established, some changes have been made to the original legislation to deal with the perceived flaws in the scheme. These changes are listed below, following Moeller(1992)'s analysis:

(a) The original scheme allowed an ongoing employer with an inadequately funded pension plan to terminate it voluntarily and effectively transfer it to the PBGC. The payment of benefits is now conditional on the company satisfying strict conditions on its degree of "distress".

(b) The initial flat premium structure allowed employers to improve benefits in pension plans that already had unfunded liabilities, increasing the insured risk to the PBGC at no extra cost in premiums. A "risk" related element was introduced, by adding a per capita premium that varies (annually) with the degree of underfunding.

(c) Apart from the practical limits imposed by increased minimum funding obligations, there were no restrictions as to benefit improvements; increases could be granted freely in an underfunded plan. Under amended law, in any case of improvements to benefits that result in less than $60 \%$ funding, collateral equal to the amount of the shortfall is required by the employer.

(d) Minimum funding standards permit the amortization of unfunded liabilities over an extended period of time (generally 30 years). As a result, most underfunded plans that terminated did not violate these standards, at least until shortly before termination. Requirements have now been strengthened somewhat for certain poorly funded plans.

(e) In the late 1970 s and early 1980 s, many terminations occurred for the purpose of returning surplus assets to the employer. These were often followed by a re-establishment of an identical pension plan, offering the same total benefits promised to employees, but with a weakened funded position thereby increasing the exposure of the.PBGC. There is now a substantial excise tax assessed against any assets returned to the employer, in addition to ordinary income tax, so this practice has been greatly curtailed. 
More recently, Bodie (1995) has criticised the PBGC's investment policy which has been undertaken to correct the abovementioned deficiency of assets in relation to actuarial liabilities. In effect, the PBGC has been undertaking increasing investment risks by mismatching equity assets against current and future pension liabilities fixed in money terms, in the hope of increasing its investment returns. Bodie points out the clear dangers in such a policy, which is essentially repeating mistakes that led to the earlier Savings and Loans problems.

Merton and Bodie (1993) have presented a general framework for analysing the management and control of guarantee programmes. Bodie and Merton (1992) have used this methodology for a detailed analysis of the possibilities for reform of and the more efficient management and control of the PBGC.

\section{APPENDIX II}

\section{Mathematical description of premium assessment methods}

\section{Risk premium approach}

In the event of a claim, it is proposed that

$$
\text { benefits }=\begin{gathered}
L_{0}^{M}-A^{M} \quad \text { if } \quad L^{M}-A^{M}>0 \\
\text { Otherwise }
\end{gathered}
$$

where $L^{M}$ and $A^{M}$ are the present value of the liabilities and assets respectively calculated on a market basis.

The risk premiums each year would be related to the difference between the present values of the liabilities and assets at the start of the year (time $t$ say), $L^{s}(t)$ and $A^{s}(t)$ respectively, calculated on a statutory solvency basis, so that the premiums automatically include a fluctuation loading. In order to utilise the time dimension for risk spreading and hence avoid a situation where high premiums are charged at a time of depressed investment values (possibly coinciding with high levels of insolvencies among employer companies), it is proposed that this difference be amortized over a period of $m$ years (where $m$ is to be specified), using an annuity factor $\ddot{a}_{\bar{m}}$ calculated at the valuation rate of interest.

Then the risk premium at time $t$ would be $P(t)$ where

$$
P(t)=p k \cdot \sum_{j=0}^{m-1} D^{s}(t-j)
$$

with $p=$ estimated probability of insolvency for the employer, which depends on the characteristics of the employer,

and

$$
\begin{aligned}
D^{s}(i) & =L^{s}(i)-A^{s}(i) \text { if } L^{s}(i)-A^{s}(i)>0 \\
& =0
\end{aligned}
$$

with

$$
i=t-j \text { and } k=(\ddot{a} \bar{m})^{-1} .
$$

If the statutory basis used is sufficiently conservative, it would be possible to use a system where the definition of $D^{s}$ is amended so that $D^{s} \neq 0$ only if $L^{s}-A^{s} \geq \varepsilon$ for some specified $\varepsilon$.

In this proposed scheme, $m$ is a control parameter to be specified. 


\section{Option pricing approach}

An important work in this area is Marcus (1987) who uses an option pricing framework for PBGC. Various earlier authors have used option pricing methodology to study the valuation of PBGC insurance e.g. in a one period framework, with automatic termination at the end of the period (Sharpe 1976, Treynor 1977) or in a qualitative analysis (Langetieg et al, 1982). The justification for this approach is that the unfunded part of a firm's pension obligations is, from the perspective of the PBGC, unsecured corporate debt. Since PBGC insurance is essentially a guarantee of long term corporate debt, it is expected that its value would behave in a manner similar to that of the implied market prices for guarantees derived from traded bond prices (Bodie and Merton 1992). If we view PBGC insurance as a put option, the pension liabilities play the role of the exercise price while the fund assets (plus the ECL, equal to $30 \%$ of net worth) play the role of the underlying stock.

Marcus (1987) develops a number of models. We consider here only the case where termination of the scheme at bankruptcy gives rise to benefits which correspond to the credit insurance system being advocated here. (Thus, the voluntary termination of the scheme is not covered). Marcus assumes that bankruptcy is declared when the value of the firm's assets, $V$, falls below the present value of the debt obligations of the firm, where this value is calculated on the basis that the obligations will be fully met. This way of considering the debt obligations, rather than market value, is the appropriate one since limited liability ensures that the market value of debt can never exceed $V$. This definition of bankruptcy attempts to represent economic insolvency (rather than technical definitions e.g. based on failing to meet a bond coupon payment).

The present value of the debt obligations, computed by discounting at the riskless (in terms of default) interest rate is denoted by $D$.

Then, bankruptcy occurs at the first occurrence of $v \leq 1$ where $v=V / D$.

Then, the credit insurance scheme would inherent a liability of $L-A$. This corresponds to an American put option with the exercise date depending on the value of $v$, an infinite maturity date and an exercise price of $L$.

To derive the present value of the insurance liabilities, $P(v, L, A)$, it is necessary to specify the dynamics of $L, A, V$ and $D$. Marcus proposes a series of diffusion processes as follows:

$$
\begin{aligned}
& d A=\left(\alpha_{A}+C_{A}\right) A d t+\sigma_{A} A d z_{A} \\
& d L=\left(\alpha_{L}+C_{L}\right) L d t+\sigma_{L} L d z_{L} \\
& d D=\alpha_{D} D d t+\sigma_{D} D d z_{D} \\
& d V=\alpha_{V} V d t+\sigma_{V} V d z_{V}
\end{aligned}
$$

where $C_{A}$ denotes the rate of contributions to the pension fund as a proportion of $A, \alpha_{A}$ represents the normal rate of return on the assets, $C_{L}$ denotes the net growth rate in accrued benefits due to demographic factors and $\alpha_{L}$ the rate of return on a bond providing a payoff stream equal to the accrued benefits. The covariances between the instantaneous rates of return on the variables are denoted by $\sigma_{D F}, \sigma_{D V}$ and so on. This structure is similar to the model of Cummins (1988) for valuing an insurance company or cohort of policies in the presence of default risk. 
Following the method of Merton (1973), it is then possible to set up a second order partial differential equation for $P(v, L, A)$ with certain boundary conditions. For constant $C_{L}$ and $C_{A}$, Marcus establishes an explicit solution. He also considers a simple representation of the tendency for pension funding policy to vary positively with the profitability of the firm via the model.

$$
C_{A}=C_{0}-\frac{C_{1}}{v}\left(C_{1}>0\right)
$$

where $C_{0}$ and $C_{1}$ are specified constants, so that funding declines with the firm's debt ratio to a minimum possible level of $C_{0}-C_{1}$. He provides numerical solutions for $P(v, L, A)$ for different values of $C_{0}$ and $C_{1}$ and, in particular, considers the relationship between $P$ and $\nu$. $\mathrm{He}$ also presents detailed empirical estimates based on this second model (and for the voluntary termination case) for 87 of the Fortune 100 companies (1982 accounts). The insurance liabilities, for this sample of companies, as a weighted proportion of vested benefits, vary from $7 \%\left(C_{1}=0.10\right)$ to $15.5 \%\left(C_{1}=0.20\right)$ and $19.6 \%\left(C_{1}=0.30\right)$.

These detailed empirical estimates of PBGC liabilities support the following conclusions:

(i) the discretionary nature of pension funding policy can lead to large PBGC liabilities. Even fully funded schemes can impose significant costs on the PBGC;

(ii) the PBGC liabilities are sensitive to small changes in ongoing pension funding policy;

(iii) the common practice of measuring liabilities as $\max (0, L-A)$ may be open to question;

(iv) PBGC reserves for future terminations (as at 1987) are far below the present value of contingent liabilities.

The use of $\max (0, L-A)$, as in the risk premium approach, for measuring liabilities under the credit insurance scheme and for use in the assessment of premiums, may not be satisfactory because it ignores the underlying dynamics of changes in $L$ and $A$ (as well as $V$ and $D$ ). The credit insurance scheme provides the employer with an option, the value of which could be much larger than the current value of the liability, $\max (O, L-A)$, because of the stochastic nature of when the option might be exercised. Indeed, as Merton (1973) has argued, it follows from conditions of arbitrage that $P(v, L, A) \geq \max (O, L-A)$.

The model and equations described earlier permit the calculation of $P$ but do not provide an explicit means for calculating fair annual premium rates for the credit insurance coverage. Two possible approaches would be as follows.

Firstly, $P(v, L, A)$, the present value of the credit insurance obligations, could be calculated at the start of each period and at the end of each period. The premium would then be equal to the change in this value of the liabilities. The advantages of this approach are that it eliminates the moral hazard element in premium rating, structures, the employer would always pay a fair premium and there would be no incentive for the employer to underfund the pension obligations at the expense of the credit insurance scheme.

Alternatively, we would calculate the expected time to bankruptcy under the model, $E$ say. Then an approximation to the fair premium rate could be obtained as the ratio of $P(v, L, A)$ to $\mathrm{a} \overline{\mathrm{E}} \mid$ where an appropriate rate of interest is used in the present value calculations. 


\section{REFERENCES}

ABRAMSON, R.B. and CARNE, S.A., "The Financing of Private Occupational Pension Schemes", presented to the Institute of Actuaries Students' Society, January 20, 1981.

BODIE, Z., "What the Pension Benefit Guaranty Corporation can learn from the Federal Savings and Loan Corporation", Journal of Financial Services Research, 10, 1995, to appear.

BODIE, Z. and MERTON, R.C., "Pension Benefit Guarantees in the United States: A Functional Analysis", 1992. In "The Future of Pensions in the United States". Ed: R. Schmitt. Chapter 5, Pension Research Council, Wharton School of the University of Pennsylvania.

BRIDE M. and LOMAX, M.W., "Valuation and Corporate Management in a Non-Life Insurance Company", Journal of Institute of Actuaries, 121, 1994, pp. 363-421.

COLLINS, A., "Funding and Solvency Levels for Pension Schemes", presented to the Staple Inn Actuarial Society, March 24, 1992.

CUMMINS, J.D., "Risk-based Premiums for Insurance Guaranty Funds", Journal of Finance, 43, 1988, pp. 823-839.

GOVERNMENT ACTUARY (1991). Occupation Pension Schemes 1987: Eighth Survey of the Government Actuary. HMSO, London.

KIPLING, M.R., "Small Self-Administered Schemes in Practice", presented to the Institute of Actuaries Students' Society, February 14, 1984.

LANGETIEG, T.C., FINDLAY, M.C. and DA MOTTA, L.F.J., "Multiperiod Pension Plans and ERISA", Journal of Financial and Quantitative Analysis, 17, 1982, pp. 603-631.

LEWIN, C.G., "A Compensation Scheme - The Pros and Cons.", presented to Autumn Conference of National Association of Pension Funds, November 1992, London.

McGILL, D.M. and GRUBBS, D.S.,"Fundamentals of Private Pensions". Sixth Edition, 1989. Homewood, Illinois, R.D. Irwin.

McLEISH, D.J.D. and STEWART, C.M., "The Supervision and Control of Pension Funding in the United Kingdom", Journal of the Institute of Actuaries, 120, 1993, pp. 67-129 (with discussion).

MARCUS, A.J., "Corporate Pension Policy and the Value of PBGC Insurance". In "Issues in Pension Economics". Ed: Z. Bodie, J.B. Shoven and D.A. Wise. Chapter 3, University of Chicago Press.

MARSHALL, D.R. and REEVE, J.G., "Defined Benefit Pension Schemes Funding for Ongoing Security", presented to the Staple Inn Actuarial Society, February 2, 1993.

MERTON, R.C., "The Theory of Rational Option Pricing", Bell Journal of Economics and Management Science, 4, 1973,pp. 141-183.

MERTON, R.C. and BODIE, Z., "On the Management of Financial Gurantees", Financial Management, 21, 1993, pp. 87-109.

MOELLER, M., "The Pros and Cons of a Compensation Scheme: The American Experience", presented to Autumn Conference of National Association of Pension Funds, November 1992, London.

PUZEY, A.S., "The Security of Occupational Pension Benefits". Occasional Actuarial Research Discussion Paper No. 23, 1979. Institute of Actuaries, London.

Report of OPB in Accordance with Section 66 of Social Security Act 1973 (1982). "Greater Security for the Rights and Expectations of Members of Occupational Pension Schemes". Cmnd 8649. London, HMSO.

Second Report of the House of Commons Select Committee on Social Security (1992). "The Operation of Pension Funds". HC 61-II. London, HMSO.

SHARPE, W.F. "Corporate Pension Funding Policy", Journal of Financial Economics, Financial 4, 1976, pp. 183-193.

TREYNOR, J.L., "The Principles of Corporate Pension Finance", Journal of Finance, 32, 1977, pp. 627-638.

URRUTIA, J., "The Cost of Deposit Insurance: Derivation of a Risk-adjusted Premium", Insurance: Mathematics and Economics, 9, 1990, pp. 281-290. 